Jurnal Keperawatan Silampari

Volume 4, Nomor 2, Juni 2021

e-ISSN: 2581-1975

p-ISSN: 2597-7482

DOI: https://doi.org/10.31539/jks.v4i2.1925

IDMEKPE

\title{
HIPNOTERAPI SUGESTI LANGSUNG DAN ANCHORING TERHADAP PENURUNAN KECEMASAN DAN TINGKAT DEPRESI PADA PASIEN ODHA
}

\author{
Sugiyono ${ }^{1}$, Rohman Azzam ${ }^{2}$, Mustikasari ${ }^{3}$, Wati Jumaiyah ${ }^{4}$, Dian Novianti $\mathrm{K}^{5}$ \\ Universitas Muhammadiyah Jakarta ${ }^{1,2,3,4,5}$ \\ sugiyononers@gmail.com ${ }^{1}$
}

\begin{abstract}
ABSTRAK
Penelitian ini bertujuan untuk mengetahui pengaruh hipnoterapi sugesti langsung dan anchoring terhadap penurunan tingkat kecemasan dan depresi pada pasien ODHA di RSUD Tarakan Jakarta Pusat. Metode penelitian ini menggunakan quasi experiment design. Hasil uji chi-square menunjukkan bahwa setelah dilakukan intervensi diperoleh tingkat kecemasan dan depresi pada kelompok intervensi dan kontrol untuk variabel kecemasan p: $1.000(>0,05)$ dan depresi p: 0,621 (> 0,05). Namun sebelum dan sesudah terjadi perubahan yang signifikan pada nilai kecemasan (16,7\%), depresi (33\%) setelah hipnoterapi. Simpulan, tidak ada pengaruh pemberian hipnoterapi sugesti langsung dan teknik anchoring terhadap penurunan tingkat kecemasan dan depresi pada pasien ODHA.
\end{abstract}

Kata Kunci: Anchoring, Depresi, Hipnoterapi Sugesti Langsung, Kecemasan, ODHA

\begin{abstract}
This study aims to determine the effect of direct suggestion hypnotherapy and anchoring on reducing levels of anxiety and depression in PLWHA patients at Tarakan Hospital, Central Jakarta. This research method uses Quasi Experiment Design. The results of the Chi-square test showed that after the intervention, the level of anxiety and depression was obtained in the intervention and control groups for the anxiety variables p: 1,000 (>0.05) and depression p: 0.621 (> 0.05). However, before and after, there was a significant change in the value of anxiety (16.7\%), depression (33\%) after hypnotherapy. In conclusion, there is no effect of giving direct suggestion hypnotherapy and anchoring techniques on reducing levels of anxiety and depression in PLWHA patients.
\end{abstract}

Keywords: Anchoring, Depression, Direct Suggestion Hypnotherapy, Anxiety, PLWHA

\section{PENDAHULUAN}

Human Immunodeficiency Virus (HIV) merupakan virus yang menyebar melalui cairan tubuh tertentu dan menyerang sistem kekebalan tubuh. Seiring waktu, HIV juga dapat menghancurkan begitu banyak sel lain sehingga tubuh tidak bisa melawan infeksi dan penyakit (CDC, 2019). Perkembangan lanjut dari infeksi ini dapat menimbulkan Acquired Immunodeficiency Syndrome (AIDS). Orang dengan HIV/AIDS (ODHA) dapat mengalami berbagai masalah, termasuk kecemasan dan depresi. Kedua hal ini 
dapat terjadi pada semua fase infeksi HIV dan keadaan stres ini akan membuat kondisi ODHA semakin memburuk (Fendina et al., 2018).

Saat ini HIV/AIDS terus menjadi masalah kesehatan publik International utama tak terkecuali Indonesia dan sejauh ini telah merenggut lebih dari 32 juta jiwa. Namun, dengan meningkatnya akses ke pencegahan, diagnosis, pengobatan dan perawatan HIV yang efektif, termasuk untuk infeksi oportunistik, infeksi HIV telah menjadi kondisi kesehatan kronis yang dapat dikelola secara baik, ODHA memungkinkan untuk menjalani hidup yang panjang, berkualitas dan sehat. Akhir 2018 dilaporkan sekitar 37,9 juta orang yang hidup dengan HIV (Andri et al., 2020; Sididi et al., 2020; WHO, 2019).

Dampak lanjut pada orang dengan HIV/AIDS (ODHA) dapat mengalami berbagai masalah, termasuk kecemasan dan depresi. Kedua hal ini dapat terjadi pada semua fase infeksi HIV dan keadaan stres ini akan membuat kondisi ODHA semakin memburuk (Fendina et al., 2018). Menurut Verhey et.,al (2018) sebanyak 204 peserta dinilai, 91 $(44,6 \%)$ adalah positif didiagnosis HIV, sebanyak 40 pasien $(19,6 \%)$ mengalami kecemasan. Sementara angka kejadian depresi pada ODHA di seluruh dunia diperkirakan mencapai 350 juta. Stigma dan diskriminasi masyarakat terhadap orang dengan HIV/AIDS (ODHA) berkembang secara luas, berakibat memburuknya kondisi ODHA baik fisik maupun psikologis (Sarkar et al., 2019). Hal ini berdampak pada perilaku ODHA yang menyembunyikan status HIV takut untuk melakukan test HIV dan menunda pengobatan (Mahaendriningtiyastuti et al., 2018; Wicaksono et al., 2018).

Depresi muncul sebagai dampak stigma dan diskriminasi masyarakat yang menilai bahwa ODHA adalah manusia pendosa, sedangkan dihukum karena perbuatannya sehingga harus dijauhi, hal ini sangat menyulitkan ODHA untuk melakukan aktivitas yang biasa dikerjakan sebelum terinfeksi HIV, situasi ini berdampak pada psikologi ODHA, mereka merasakan penyesalan yang mendalam, marah, kecewa, bingung, putus asa dan tidak mempunyai harapan lagi untuk masa depan. Religiusitas berperan dalam mengurangi depresi (Prasojo, 2017).

Stigma dan diskriminasi pada ODHA akan menjadi stres bagi penderitanya. Stres memiliki dampak yang kurang baik bagi kesehatan orang dengan HIV/AIDS, dalam upaya menangani stres, seorang individu membutuhkan koping stres yang tepat (Andrianto et al., 2020; Indriani \& Fauziah, 2017).

Berbagai intervensi untuk mengatasi hal tersebut telah dilakukan pemerintah seperti edukasi dan konseling, terapi kognitif perilaku religius, kelompok bermain, medikasi dan hypnoterapi, namun teknik hypnoterapi sendiri belum banyak diterapkan sabagai alternatif dalam mengatasi hal tersebut. Dari berbagai penelitian, teknik hypnoterapi dinilai efektif untuk menurunkan kecemasan dan depresi, namun secara spesifik pada kasus HIV/AIDS masih sangat jarang ditemukan.

Tindakan ini tertuang dalam Permenkes RI nomor 26 tahun 2019 tentang peraturan pelaksanaan UU nomor 38 tahun 2014 tentang keperawatan khususnya pasal 21 ayat (1) huruf $m$, dimana perawat memiliki kewenangan melakukan penatalaksanaan keperawatan komplementer dan alternatif (Permenkes RI Nomor 26 Tahun 2019 Tentang Peraturan Pelaksanaan UU Nomor 38 Tahun 2014 TENTANG Keperawatan, 2019). Selain itu hypnoterapi merupakan intervensi keperawatan yang tertuang dalam Standar Intervensi Keperawatan Indonesia (SIKI PPNI, 2018). Dalam hypnoterapi, kekuatan sugestif dapat menghasilkan efek terapeutik. Sedikitnya terdapat 12 teknik yang dapat digunakan dalam hypnoterapi termasuk teknik direct sugestion dan anchoring. 
Beberapa penelitian hypnoterapi yang dilakukan oleh Valentine et al., (2019) dari study meta-analysis terdapat 399 catatan yang disaring ini mengukur efektivitas hipnosis dalam mengobati kecemasan dengan hasil lebih efektif ketika dikombinasikan dengan intervensi psikologis lain.

Berdasarkan fenomena dan permasalahan yang terjadi dan belum pernah dilakukan penelitian yang sama, maka menjadi penting untuk mengetahui secara spesifik pengaruh pemberian hypnoterapi direct sugestion dan teknik anchoring terhadap penurunan tingkat kecemasan dan depresi pada pasien ODHA di RSUD Tarakan Jakarta Pusat Tahun 2020.

\section{METODE PENELITIAN}

Penelitian ini tergolong penelitian komparatif dengan pendekatan quasi eksperimental design. Teknik pengambilan sampel dilakukan dengan menggunakan cara purposive sampling. Teknik penetapan sampel dengan cara memilih sampel diantara populasi sesuai dengan yang dikehendaki peneliti (tujuan/masalah peneliti), sehingga sampel tersebut dapat mewakili karakteristik populasi yang ada. Jumlah populasi dalam penelitian ini sebanyak 72 orang, kemudian diambil secara acak 36 untuk kelompok intervensi (hypnoterapi) dan 36 untuk kelompok kontrol (tidak hypnoterapi).

Variabel kecemasan menggunakan kuisioner Back Anxiety Index (BAI) dan depresi menggunakan Back Depresion Index (BDI), dilakukan sebelum dan setelah perlakuan pada kelompok intervensi maupun kontrol. Hasil dari BDI dan BAI dianalisis menggunakan uji chi-Square.

Penelitian telah dilakukan di RSUD Tarakan dengan pertimbangan bahwa masih tingginya kejadian orang dengan HIV/AIDS (ODHA) dan menjadi pusat rujukan Jakarta pusat pada bulan Juni 2020. Metode yang digunakan untuk mengontrol variabel perancu dengan cara dirandom dalam pengambilan sampelnya sehingga komposisi kelompok intervensi dan kontrol bisa sama.

\section{HASIL PENELITIAN Analisa Univariat}

Tabel. 1

Karakteristik Responden Berdasarkan Usia, Jenis Kelamin, Pendidikan,

Pekerjaan, Penghasilan dan Dukungan Sebaya

\begin{tabular}{|c|c|c|c|c|c|c|c|}
\hline \multirow{2}{*}{\multicolumn{2}{|c|}{ Variabel }} & \multicolumn{2}{|c|}{$\begin{array}{l}\text { Kelompok } \\
\text { Intervensi }\end{array}$} & \multicolumn{2}{|c|}{$\begin{array}{c}\text { Kelompok } \\
\text { Kontrol }\end{array}$} & \multicolumn{2}{|c|}{ Total } \\
\hline & & $\mathrm{N}$ & $\%$ & $\mathrm{~N}$ & $\%$ & $\mathrm{n}$ & $\%$ \\
\hline \multicolumn{8}{|l|}{ Usia } \\
\hline & 17-25 Tahun & 8 & 22,2 & 7 & 19,4 & 15 & 20,8 \\
\hline & 26-35 Tahun & 9 & 25,0 & 9 & 25,0 & 18 & 25,0 \\
\hline & 36-45 Tahun & 12 & 33,3 & 18 & 50,0 & 30 & 41,7 \\
\hline & 46-55 Tahun & 7 & 19,4 & 2 & 5,6 & 9 & 12,5 \\
\hline \multicolumn{8}{|c|}{ Jenis Kelamin } \\
\hline & Laku-Laki & 20 & 55,6 & 20 & 55,6 & 40 & 55,6 \\
\hline & Perempuan & 16 & 44,4 & 16 & 44,4 & 32 & 44,4 \\
\hline \multicolumn{8}{|c|}{ Pendidikan } \\
\hline & SD & 1 & 2,8 & 1 & 2,8 & 2 & 2,8 \\
\hline & SLTP & 13 & 36,1 & 14 & 38,9 & 27 & 37,5 \\
\hline & SLTA & 17 & 47,2 & 12 & 33,3 & 29 & 40,3 \\
\hline & $\mathrm{S} 1 / \mathrm{S} 2$ & 5 & 13,9 & 9 & 25,0 & 14 & 19,4 \\
\hline
\end{tabular}




\begin{tabular}{ccccccc}
\hline Pekerjaan & & & & & & \\
Tidak & 5 & 13,9 & 6 & 16,7 & 11 & 15,3 \\
Bekerja & 8 & 22,2 & 5 & 13,9 & 13 & 18,0 \\
Karyawan & 13 & 36,1 & 15 & 41,7 & 28 & 38,9 \\
Wiraswasta & 10 & 27,8 & 10 & 27,8 & 20 & 27,8 \\
Buruh & 14 & 38,9 & 16 & 44,4 & 30 & 41,7 \\
\hline Penghasilan & 22 & 61,1 & 20 & 55,6 & 42 & 58,3 \\
\hline 5 Juta & 21 & 58,3 & 23 & 63,9 & 44 & 61,1 \\
<5 Juta & 14 & 38,9 & 13 & 36,1 & 27 & 37,5 \\
\hline Dukungan Sebaya & & & & & & 1,4 \\
Kering & 1 & 2,8 & 0 & 0 & 1 & \\
Kadang- & & & & & & \\
Tidak & & & & &
\end{tabular}

Berdasarkan tabel 1 menunjukkan bahwa mayoritas usia kedua kelompok adalah usia 36-45 tahun sebanyak 30 orang dengan persentase 41,7\%. Mayoritas jenis kelamin kedua kelompok adalah jenis kelamin laki-laki sebanyak 40 orang dengan persentase 55,6\%. Mayoritas pendidikan responden kedua kelompok adalah pendidikan SLTA, yaitu sebanyak 29 orang dengan persentase 40,3\%. Mayoritas pekerjaan responden kedua kelompok adalah wiraswasta, yaitu sebanyak 28 orang dengan persentase $38,9 \%$. Mayoritas penghasilan <5 juta kedua kelompok yaitu sebanyak 42 orang dengan persentase $58,3 \%$. Mayoritas dukungan kelompok sebaya kedua kelompok adalah sering sebanyak 44 orang dengan persentase $61.1 \%$.

\section{Analisa Bivariat}

Tabel. 2

Perubahan Tingkat Kecemasan dan Depresi pada Pasien ODHA

Sebelum dan Setelah Hypnoterapi pada Kelompok Intervensi

\begin{tabular}{cccccc}
\hline Variabel & Intervensi & Tingkat & $\mathrm{n}$ & $\%$ & p-value \\
\hline \multirow{3}{*}{ Kecemsan } & \multirow{2}{*}{ Sebelum } & Sedang & 33 & 91.7 & \\
& & Berat & 3 & 8.3 & \multirow{2}{*}{0.148} \\
\cline { 2 - 5 } & \multirow{2}{*}{ Setelah } & Sedang & 27 & 75 & \\
& \multirow{3}{*}{ Sebelum } & Berat & 9 & 25 & \\
& & Borderline & 8 & 22.2 & \\
& & Sedang & 25 & 69.4 & \\
& \multirow{3}{*}{ Sepresi } & Berat & 3 & 8.3 & \multirow{2}{*}{0.188} \\
& \multirow{2}{*}{ Setelah } & Normal & 1 & 2.8 & \\
& & Ringan & 6 & 16.7 & \\
& & Borderline & 16 & 44.4 & \\
& & Sedang & 13 & 36.1 & \\
\hline
\end{tabular}

Berdasarkan tabel 2 menunjukkan bahwa tingkat kecemasan pada kelompok intervensi sebelum dan setelah dilakukan hypnoterapi didapatkan persentase setelah dilakukan hypnoterapi menunjukkan selisih 6 responden $(16,7 \%)$ pada tingkat kecemasan sedang lebih rendah sebelum dilakukan hipnoterapi, dengan menunjukkan hasil nilai p-value $=0,148(>0,05)$ sehingga dapat disimpulkan bahwa tidak ada perubahan yang signifikan pada tingkat kecemasan sebelum dan sesudah intervensi. 
Sedangkan tingkat depresi pada kelompok kontrol sebelum dan setelah dilakukan hypnoterapi menunjukkan tingkat depresi berat dan sedang dengan sebanyak 28 responden $(77,7 \%)$, setelah dihypnoterapi menunjukkan tingkat depresi ke tingkat borderline 18 responden (50\%). Uji statistik dengan didapatkan nilai p-value $=0,188$ $(<0.05)$ sehingga dapat disimpulkan bahwa tidak ada perubahan yang signifikan pada tingkat depresi sebelum dan sesudah intervensi.

Tabel. 3

Perubahan Tingkat Kecemasan dan Depresi pada Pasien ODHA

Sebelum dan Setelah Hypnoterapi pada Kelompok Kontrol

\begin{tabular}{|c|c|c|c|c|c|}
\hline Variabel & Intervensi & Tingkat & $\mathrm{N}$ & $\%$ & p-value \\
\hline \multirow[t]{4}{*}{ Kecemasan } & Sebelum & Sedang & 34 & 94,4 & 1,000 \\
\hline & & Berat & 2 & 5,6 & \\
\hline & Setelah & Sedang & 11 & 30,6 & \\
\hline & & Berat & 25 & 69,4 & \\
\hline \multirow[t]{7}{*}{ Depresi } & Sebelum & Borderline & 7 & 19,4 & 0,006 \\
\hline & & Sedang & 29 & 80,6 & \\
\hline & & Berat & 3 & 0 & \\
\hline & & Normat & 0 & 0 & \\
\hline & & Ringan & 0 & 0 & \\
\hline & & Borderline & 9 & 25 & \\
\hline & & Sedang & 27 & 75 & \\
\hline
\end{tabular}

Berdasarkan tabel 3 menunjukkan bahwa tingkat kecemasan pada kelompok kontrol sebelum dan setelah dilakukan hypnoterapi didapatkan persentase tingkat kecemasan berat terlihat lebih meningkat dari kecemasan sebelumnya pada tingkat berat terdapat selisih kenaikan sebanyak 23 responden $(63,8 \%)$ dengan menunjukkan hasil nilai $\mathrm{p}$-value $=1,00$ (>0.05) sehingga tidak ada perubahan yang signifikan pada tingkat kecemasan sebelum dan sesudah pada kelompok kontrol.

Sedangkan tingkat depresi pada kelompok kontrol menunjukkan lebih rendah pada depresi sedang sebanyak 2 responden persentasenya $(5,6 \%)$ pada depresi sedang. Uji statistik dengan didapatkan nilai p-value $=0,006 \quad(<0,05)$ sehingga dapat disimpulkan bahwa ada perubahan yang signifikan pada tingkat depresi sebelum dan sesudah pada kelompok intervensi.

Tabel. 4

Perubahan Tingkat Kecemasan dan Depresi Sebelum dan Setelah Pemberian Hypnoterapi (Direct Sugestion dan Anchoring) pada Kelompok Intervensi dan Kontrol

\begin{tabular}{|c|c|c|c|c|c|c|}
\hline \multirow{2}{*}{ Variabel } & \multirow{2}{*}{ Kelompok } & \multicolumn{4}{|c|}{ Distribusi \% } & \multirow{2}{*}{ p-value } \\
\hline & & Pre & Post & Selisih & $\mathrm{n}$ & \\
\hline \multirow[t]{2}{*}{ Kecemasan } & Intervensi & 91,7 & 75 & 16,7 & 36 & \multirow{2}{*}{1,000} \\
\hline & Kontrol & 91,7 & 30,6 & 16,1 & 36 & \\
\hline \multirow[t]{2}{*}{ Depresi } & Intervensi & 77,8 & 36,2 & 41,6 & 36 & \multirow{2}{*}{0,621} \\
\hline & Kontrol & 77,8 & 75 & 2,8 & 36 & \\
\hline
\end{tabular}

Berdasarkan tabel 5 menunjukkan bahwa tingkat kecemasan sebelum dan setelah dilakukan hypnoterapi pada kelompok kontrol lebih tinggi 61,1\% dari pada kelompok intervensi $16,7 \%$. Hasil uji statistik pada kedua kelompok didapatkan p-value $=1,000$ (>0.005) sehingga dapat disimpulkan bahwa tidak ada perubanan yang signifikan pada tingkat kecemasan sebelum dan sesuadah pada kelompok intervesni dan kontrol. 
Sedangkan tingkat depresi sebelum dan setelah dilakukan hypnoterapi pada kelompok intervensi lebih tinggi 41,6\% dari pada kelompok kontrol 2,8\%. Hasil uji statistik pada kedua kelompok didapatkan p-value $=0.621(>0.005)$ sehingga dapat disimpulkan bahwa tidak ada perubahan yang signifikan pada tingkat kecemasan sebelum dan sesuadah pada kelompok intervensi dan kontrol.

\section{PEMBAHASAN}

\section{Perubahan Tingkat Kecemasan dan Depresi Sebelum dan Setelah Pemberian Hypnoterapi Direct Sugestion dan Anchoring pada Kelompok Intervensi}

Hasil penelitian menunjukkan bahwa tidak ada perubahan yang signifikan tingkat kecemasan dan depresi sebelum dan sesudah pemberian hypnoterapi direct sugestion dan anchoring pada kelompok intervensi di RSUD Tarakan. Walaupun hasil menunjukkan tidak ada perubahan signifikan, namun hasil analisis secara presentase menunjukkan adanya perubahan dalam tingkat kecemasan setelah dilakukan intervensi terjadi penurunan tingkat kecemasan dan depresi. Sehingga berdasarkan persentase tersebut dapat disimpulkan ada perubahan sebelum dan setelah dilakukan hypnoterapi pada tingkat kecemasan dan depresi pada kelompok intervensi.

Hal ini tidak sejalan dengan beberapa penelitian sebelumnya tentang manfaat hypnoterapi yang dilakukan oleh Valentine et al., (2019) dari study meta-analysis terdapat 399 catatan yang disaring ini mengukur efektivitas hipnosis dalam mengobati kecemasan dengan hasil lebih efektif ketika dikombinasikan dengan intervensi psikologis lain.

Peneliti berasumsi bahwa tidak ada perubahan siginifikan nilai tingkat kecemasan dan depresi pada kelompok intervensi tersebut bisa terjadi karena pada saat pengambilan data responden masih belum meyakini manfaat dan cara kerja hypnoterapi, dan hal ini perlu dilakukan secara berulang ulang untuk menjelaskan manfaat hypnoterapi secara medis atau kesehatan. Ditambah dengan adanya rasa kurang yakin akan manfaat hypnoterapi tersebut, hal akan mempengaruhi tingkat sugestif terhadap responden sehingga peneliti mengalami kesulitan untuk memasuki alam bawah sadarnya.

Peneliti juga berpendapat adanya faktor lingkungan saat hypnoterapi yang kurang kondusif karena pada saat penelitian peneliti masih melakukan hypnoterapi di ruangan poliklinik VCT yang belum memenuhi standar dan ruangan tersebut masih bergabung dengan layanan pasien ODHA lain, sehingga terdapat suara bising didengar, percakapan orang berbicara masih terdengar jelas sehingga mempengaruhi tingkat konsentrasi responden. Penyebab lain dari peneliti juga berasumsi pelaksanaan waktu hypnoterapi dilakukan secara bersamaan dengan responden lain sehingga mengganggu kenyamanan responden dan adanya rasa saling menjaga privasi terhadap dirinnya dan sebaiknya bisa dilakukan secra individu satu pasien satu kali tatap muka.

Dalam terapi hypnoterapi, masalah lain yang didapatkan pada saat pengambilan data adalah hanya dilakukan selama dua minggu dan satu kali intervensi dalam seminggu. Menurut Ahmad \& Agustin (2019) menyebutkan perubahan signifikam dengan pemberian hypnoterapi 5 jari diberikan selama 40 menit setiap pertemuan, yang dilakukan selama 6 hari (6 x pertemuan) didapatkan adanya penurunan tingkat kecemasan pada permasalahan psikologis.

Walaupun tingkat kecemasan dan depresi sebelum dilakukan intervensi lebih tinggi dari pada sebelumnya, peneliti meyakini adanya perubahan pada tingkat kecemasan dan depresi disebabkan kareana pengaruh relaksasi pada otot dan pikiran 
sehingga memicu hormon endorphin dan susana tenang/relaks sehingga pembuluh darah didalam tubuh mengalami lebih lancar.

Penelitian yang dilakukan Ahdian et al., (2018) menyebutkan jika kecemasan terhadap kematian yang berlebih tidak diselesaikan dengan baik akan menimbulkan gangguan fungsi emosional seperti neurotisma, depresi, dan gangguan psikosomatis.

Terapi hipnoterapi merupakan salah satu bentuk self hipnosis yang dapat menimbulkan efek relaksasi yang tinggi, sehingga akan mengurangi ketegangan dan stres dari pikiran seseorang. Hipnoterapi mempengaruhi system limbik seseorang sehingga berpengaruh pada pengeluaran hormon-hormon yang dapat memacu timbulnya stres. Responden yang diberikan intervensi hypnoterapi akan mengalami relaksasi sehingga berpengaruh terhadap sistem tubuh dan menciptakan rasa nyaman serta perasaan tenang (Marbun, 2019).

Untuk pencapain hasil yang optimal dan maksimal sebaiknya latihan hypnoneteapi bisa dilkukan sendiri atau yang disebut dengan self hypnosis secara rutin selama 25-30 menit setiap sesi, dengan mengunakan audio visual media youtube streaming atau video self hypnosis lainnya. Responden juga bisa disarakan memilih tempat yang nyaman untuk, pengaturan posisi dan sikap, serta mengatur pencahayaan supaya tidak terlalu terang, modifikasi lingkungan ini merupakan elemen penting dalam pelaksanaan hypnoterapi untuk mencapai kesempurnaan dalam terapi. Waktu latihan hypnoterapi secara mandiri agar kemampuan - kemapuan baru yang di peroleh menjadi kebiasaan dan dapat digunakan sebagai strategi koping untuk mengatasi ansietas dan depresi.

Kemampuan pasien ODHA dalam menurunkan tingkat kecemasan mengalami penurunan yang bermakna secara persentase bila dibandingkan dengan kelompok kontrol. Hal ini menunjukkan perubahan bahwa hypnoterapi direct sugestion dan anchoring berpengaruh dalam menurunkan tingkat kecemasan dan depresi. Pemberian hypnoterapi masing masing pasien ODHA dilakukan 1 kali pertemuan dalam seminggu selama dua minggu ternyata mampu menurunkan tingkat kecemasan dan depresi. Hal ini bisa dilakukan secara berlanjut untuk mendapatkan hasil secara optimal dengan mengikuti program terapi dan menambah jumlah pertemuan di lakukan 2 kali seminggu atau waktu evalausi diperpanjang.

Kesimpulan akhir dinyatakan bahwa hypnoterapi dapat menurunkan tingkat kecemasan dan depresi pada ODHA dengan cara bekerja memberikan pesan sugestif melewati alam bawah sadar dan efek relaksasi yang berdampak pada aktivasi neurohormonal endorphin dan vasodilatasi pembuluh darah dengan memberikan manifestasi sensai ketenangan psikologis rasa kecemasan dan depresi.

\section{Perubahan Tingkat Kecemasan dan Depresi Sebelum dan Setelah Pemberian Hypnoterapi (Direct Sugestion dan Anchoring) pada Kelompok Kontrol}

Hasil uji statistik dengan menggunakan uji chi-square pada penelitian ini diperoleh bahwa tidak ada perubahan yang signifikan tingkat kecemasan dan depresi sebelum dan sesudah pemberian hypnoterapi: direct sugestion dan anchoring pada kelompok kontrol di RSUD Tarakan. Walaupun hasil menunjukkan tidak ada perubahan signifikan namun, Hasil persentase menunjukkan tidak ada perubahan signifikan kita bisa melihat perubahan persentase pada kelompok kontrol terdapat kenaikan tingkat kecemasan skala berat menjadi 23 responden $63.8 \%$ dari $5.6 \%$ menjadi $69.4 \%$. Pada tingkat depresi pada tingkat depres hanya didaptkan perubahan 2 responden $11 \%$ dari $75 \%$ menjadi $86 \%$. Sehingga berdasarkan presentase tersebut dapat disimpulkan tidak 
ada perubahan sebelum dan setelah dilakukan pengukuran tingkat kecemasan dan depresi pada kelompok kontrol.

Hasil penelitian ini tidak sejalan dengan Setyadi \& Yunita (2018) menunjukkan bahwa hipnoterapi efektif dalam mengurangi depresi, kecemasan, dan stres pada ODHA. Peneliti juga berasumsi bahwa perubahan nilai tingkat kecemasan dan depresi pada kelompok kontrol didapatkan karena beberapa faktor lain yang mempengaruhi pada tingkat cemasan dan depresi.

\section{SIMPULAN}

Tidak ada pengaruh pemberian hipnoterapi sugesti langsung dan teknik anchoring terhadap penurunan tingkat kecemasan dan depresi pada pasien ODHA.

\section{SARAN}

Berdasarkan hasil penelitian ini diharapkan intervensi hypnoterapi menjadi salah satu bentuk intervensi keperawatan mandiri bagi seorang perawat dalam memberikan asuhan keperawatan kepada pasien ODHA dan menjadi bahan panduan untuk memberikan pendididikan kesehatan untuk masalah tingkat kecemasan dan depresi.

Diharapkan juga menjadikan salah satu intervensi di klinik keperawatan komplementer pada pasein dengan gangguan psikosomatis

\section{DAFTAR PUSTAKA}

Ahdian, G. N., Widianti, E., \& Fitria, N. (2018). Tingkat Kecemasan terhadap Kematian pada ODHA. Jurnal Keperawatan Soedirman, 12(3), 199. https://doi.org/10.20884/1.jks.2017.12.3.758

Ahmad, B. N. H., \& Agustin, I. M. (2019). Penerapan Terapi 5 Jari pada Pasien Psikosomatis untuk Mengurangi Kecemasan di Klinik dr. Bangun di Desa Kamulyan Kecamatan Tambak. The 10th University Research Colliqium, 98-104

Andri, J., Ramon, A., Padila, P., Sartika, A., \& Putriana, E. (2020). Pengalaman Pasien ODHA dalam Adaptasi Fisiologis. Journal of Telenursing (JOTING), 2(2), 127141. https://doi.org/10.31539/joting.v2i2.1397

Andrianto, M. B., Setyawati, A. D., Muin, M., \& Motuho-Mendrofa, F. A. (2020). Koping Religius pada Kelompok Penderita HIV/AIDS. Journal of Telenursing (JOTING), 2(2), 150-157. https://doi.org/10.31539/joting.v2i2.1528

CDC. (2019). About HIV / AIDS :Division of HIVIAIDS Prevention, National Center for HIV/AIDS, Viral Hepatitis, STD, and TB Prevention, Centers for Disease Control and Prevention

Fendina, F., Nashori, F., \& Sulistyarini, I. (2018). Efektivitas Pelatihan Meditasi Pernafasan dalam Menurunkan Tingkat Stres pada Pendukung Sebaya Odha. Jurnal Psikologi Integratif, 6(1), 1. https://doi.org/10.14421/jpsi.v6i1.1470

Indriani, S. D., \& Fauziah, N. (2017). Karena Hidup Harus Terus Berjalan (Sebuah Studi Fenomenologi Kehidupan Orang dengan HIV/AIDS). Empati: Jurnal Karya Ilmiah S1 Undip, 6(1), 385-395. https://www.neliti.com/id/publications/62241/

Mahaendriningtiyastuti, Yani, E. R., \& Suwoyo, S. (2018). Stigma dan Diskriminasi Serta Strategi Koping pada Orang Dengan Hiv/Aids Dikota Ambon. Global Health Science, 3(1), 339-345 
Marbun, A. (2019). Efektivitas Terapi Hipnotis Lima Jari terhadap Kecemasan Ibu Pre Partum di Klinik Chelsea Husada Tanjung Beringin Kabupaten Serdang Bedagai. Jurnal Keperawatan Priority, 2(2), 92. https://doi.org/10.34012/jukep.v2i2.568

Permenkes RI Nomor 26 Tahun 2019 Tentang Peraturan Pelaksanaan UU Nomor 38 Tahun 2014 Tentang Keperawatan, (2019)

Prasojo, D. (2017). Peran Religiusitas pada Penderita HIV dan AIDS yang Mengalami Depresi. Jurnal Studia Insania, 5(1), 46-70. https://doi.org/10.18592/jsi.v5i1.1270

Sarkar, T., Karmakar, N., Dasgupta, A., \& Saha, B. (2019). Stigmatization and Discrimination Towards People Living with HIV/AIDS Attending Antiretroviral Clinic in a Centre of Excellence in HIV Care in India. International Journal of Community Medicine And Public Health, 6(3), 1241. https://doi.org/10.18203/2394-6040.ijcmph20190619

Setyadi, A. W., \& Yunita, A. (2018). The Effect of Hypnotherapy to the Changes of Stres Level to Odha ( person who has been diagnosed HIV / AIDS ) in the KDS Friendship Plus Kediri. In The 2nd Joint International Conferences, 2(2), 11-18

Sididi, M., Rahman, R., \& Yusriani, Y. (2020). High Risk Behaviour Tertular HIV/AIDS pada Anak Buah Kapal. Jurnal Kesmas Asclepius, 2(2), 88-96. https://doi.org/10.31539/jka.v2i2.1470

SIKI PPNI. (2018). Standar Intervensi Keperawatan Indonesia (SIKI): Definisi dan Tindakan Keperawatan (Tim Pokja SIKI DPP PPNI, Ed.; Cetakan II)

Valentine, K. E., Milling, L. S., Clark, L. J., \& Moriarty, C. L. (2019). The Efficacy of Hypnosis As a Treatment for Anxiety: a Meta-Analysis. International Journal of Clinical and Experimental Hypnosis, 67(3), 336-363. https://doi.org/10.1080/00207144.2019.1613863

Verhey, R., Chibanda, D., Gibson, L., Brakarsh, J., \& Seedat, S. (2018). Validation of the posttraumatic stres disorder checklist - 5 (PCL-5) in a primary care population with high HIV prevalence in Zimbabwe. BMC Psychiatry, 18(1), 1-8. https://doi.org/10.1186/s12888-018-1688-9

WHO. (2019). HIV \& AIDS Key facts. World Health Organization, 22(7), 1. https://www.who.int/news-room/fact-sheets/detail/hiv-aids

Wicaksono, Y. A., Fitrikasari, A., Sofro, M. A. U., \& Peni, H. (2018). Hubungan Stigma dan Terapi ARV dengan Komplikasi Gangguan Psikiatri pada Pasien HIV/AIDS. Jurnal Penyakit Dalam Indonesia, 5(1), 24. https://doi.org/10.7454/jpdi.v5i1.161 